Int. J. Electrochem. Sci., 12 (2017) 4898 - 4914

\title{
Electrodeposition of Nanostructured ZnO Photoanodes for Their Application in the Oxygen Evolution Reaction
}

\author{
F. D. Ruiz-Ocampo ${ }^{1}$, J. M. Zapien-Rodríguez ${ }^{1}$, O. Burgara-Montero ${ }^{1}$, E. A. Escoto-Sotelo ${ }^{1}$, \\ F. A. Núñez-Pérez ${ }^{1, *}$, and J. C. Ballesteros-Pacheco ${ }^{1, *}$ \\ ${ }^{1}$ Universidad Politécnica de Lázaro Cárdenas, Laboratorio de Sustentabilidad Energética, Av. \\ Galeanas S/N, Colonia Las 600 Casas S/N, C.P. 60950, Lázaro Cárdenas, Michoacán, México. \\ *E-mail: jballesteros_pacheco@yahoo.com.mx, phd_paco@hotmail.com
}

doi: $10.20964 / 2017.06 .74$

Received: 22 February 2017 / Accepted: 12 April 2017 / Published: 12 May 2017

In this work it is reported by first time the galvanostatic electrodeposition of nanostructured $\mathrm{ZnO}$ films on indium tin oxide (ITO) substrates from oxygenated-neutral solution containing $\mathrm{Zn}\left(\mathrm{CH}_{3} \mathrm{COO}\right)_{2}$ and $\mathrm{K}\left(\mathrm{CH}_{3} \mathrm{COO}\right)$ at different temperature from 50 to $70^{\circ} \mathrm{C}$. Morphological, structural, UV-vis spectra, photoluminescence spectra and photoelectrochemical tests of the electrodeposited $\mathrm{ZnO}$ films were measured. The synthesis conditions studied were the parameters temperature and applied current density. SEM results show $\mathrm{ZnO}$ films with grains of hexagonal shape, which present different grain size $(150-600 \mathrm{~nm})$ as a function of the studied parameters. The optical properties of $\mathrm{ZnO}$ films show absorption in the UV-visible region with band gap energy values from 2.92 to $3.15 \mathrm{eV}$. Through a XRD analysis, we show that the electrodeposition conditions also have an effect in the intensity of (002) polar and (100) no polar planes of electrodeposited $\mathrm{ZnO}$ films. Additional results by photoluminescence indicate presence of oxygen vacancies in the electrodeposited $\mathrm{ZnO}$ films, which is a factor considered as responsible of enhance electroactivity of $\mathrm{ZnO}$ films for oxygen evolution reaction in visible region. Calculations of overall solar to hydrogen efficiency for electrodeposited $\mathrm{ZnO}$ films indicate a maximum value of approximately $\eta=0.65 \%$ for $\mathrm{ZnO}$ film obtained at $\mathrm{j}=-1.0$ $\mathrm{mA} \mathrm{cm}{ }^{-2}$ and $70^{\circ} \mathrm{C}$.

Keywords: Oxygen Evolution Reaction; Zinc Oxide; Electrodeposition; Electrocatalyst.

\section{FULL TEXT}

(C) 2017 The Authors. Published by ESG (www.electrochemsci.org). This article is an open access article distributed under the terms and conditions of the Creative Commons Attribution license (http://creativecommons.org/licenses/by/4.0/). 